УДК 821.161 .1

ББК $83.3(2)$

\section{М.А. Медведева}

\section{P.П. КУМОВ \\ И А.М. ГОРЬКИЙ: \\ ИСТОРИЯ \\ ЛИТЕРАТУРНЫХ ОТНОШЕНИЙ}

Рассматривается история литературных отношений Р.П. Кумова и А.М. Горького. Анализируется переписка писателей, позволяющая выявить роль А.М. Горького в творческой биографии Р.П. Кумова. Устанавливаются типологические связи между романом A.M. Горького «Дело Артамоновых» и драмой Р.П. Кумова «Конец рода Коростомысловых».

Ключевые слова: Р.П. Кумов, А.М. Горький, литературные отношения, творческая биография.

DOI 10.18522/1995-0640-2020-2-161-170

Медведева Мария Александровна - ассистент кафедры русского языка как иностранного Института русского языка и словесности Волгоградского государственного социально-педагогического университета

Тел: + 7 (927) 065-90-66

E-mail: mary-medved.medvedeva@yandex.ru

(C) Медведева М.А., 2020.
20 декабря 1924 г. в письме К. Федину из Сорренто Горький задает адресату вопрос: «Не слышали ли имя Роман Кумов? Где он? Он выпустил небольшую книжку рассказов и написал пьесу „Конец рода Коростомысловых”, еще до войны. Интересный» [Горький и советские писатели, 1963, с. 483]. К. Федин ответил: «Имени Роман Кумов я не встречал, и узнать о нем не удалось» [Там же, с. 491].

Между тем, Роман Петрович Кумов (1887-1919) был одним из самых известных донских литераторов Серебряного века. Его литературный талант получил широкое признание читателей, критики, целого ряда писателей-современников. Особенно значимо в этом ряду имя Максима Горького.

После выхода первого прозаического сборника «Бессмертники» (1909) Кумов заявил о себе как о писателе духовно-религиозной ориентации. В центре большинства рассказов сборника - православные священнослужители из глухих сел и небольших провинциальных городов. Стремясь осмыслить место и роль сельского пастыря в русском обществе, Кумов делает акцент на ежедневном духовном подвижничестве своих героев. Одно из центральных мест в его первом сборнике и дальнейшем творчестве писателя занимают произведения, развивающие религиозно-философскую тему бессмертия души, которая осмысливается им в русле православнохристианской традиции [Медведева, Гольденберг, 2015].

Второй сборник писателя «В Татьянину ночь» (1913) привлек к себе повышенный интерес крити- 
ков. Кумов остается верен духовно-религиозной проблематике, однако в его творчестве появляются новые темы и герои, расширяется художественная палитра писателя. Героями произведений сборника становятся представители провинциальной и сельской интеллигенции, чьи духовные искания и судьбы прослеживает автор. Новое осмысление получает тема служения сельского священника. Если в рассказах, составивших сборник «Бессмертники», автор выдвигает на первый план проблему духовного подвига сельского священника, то в рассказе «Юбилей», вошедшем во второй сборник, эта проблема приобретает остросоциальное звучание. Герой рассказа сельский священник отец Варнава празднует пятьдесят лет своего служения в глухой деревушке. Он ждет гостя, который должен написать статью для «Епархиальных ведомостей» о его юбилее. Варнава просит его, чтобы статья поведала не столько о юбиляре, сколько о нелегком служении сельского священника: «врачебной помощи нет, жить не на что, детей учить далеко... <... Вот эта деревушка, <..> разве она была описана? Разве знают на свете, как здешний мужик страшно голодает, страшно пьянствует, какой он кругльии невежда, как он беспомощен во всем, как ребенок, и как мягок и добр, несмотря на нужду и болезни?» [Кумов, 1913, с. 47-48]. Публиковать такого рода статью ни церковный, ни светский журнал не решились, и пастырю приходится обратиться к зарубежной печати. Совершенно новым явлением в творчестве Кумова становятся сатирические рассказы, в которых комизм сюжетных ситуаций обнажает социальные противоречия («Несчастье», «Проповедь», «Ученый»). Так, герой рассказа «Проповедь», молодой сельский священник отец Поликарп, обличает на своей проповеди кулака-трактирщика. Священник, зная о том, каким влиянием пользуется содержатель трактира в селе, мысленно сравнивает себя с древними христианскими мучениками, полагая, что ему неизбежно придется пострадать за свои убеждения. Однако финал рассказа почеховски комичен: кулак-трактирщик просит взыскать со священника деньги на лечение, поскольку он простудился, слушая в храме слишком долгую проповедь. Таким образом, комический эффект рассказа построен на контрасте между возвышенными идеалами героя и сельской действительностью, в которой содержатель трактира считается видным общественным деятелем.

Горькому принадлежит один из первых критических откликов на сборник Кумова. В рецензии на него, опубликованной в журнале «Современник», он отмечает как сильные, так и слабые стороны таланта писателя. Горький-рецензент не дает развернутой оценки всей книги. Его интересуют лишь те произведения донского писателя, в которых явственно звучат ноты социальной критики. Он пишет и о сильном влиянии А.П. Чехова на творчество Кумова, которое, впрочем, было единодушно отмечено в других критических отзывах о сборнике.

Именно в этой зависимости от А.П. Чехова Горький видит основной недостаток стиля Кумова. Начиная свою рецензию с рассмотрения рассказа «Турист», открывающего книгу, он замечает: «Есть в этом что-то 
правдиво русское, нелепое и жалкое, но еще более - подражание Чехову, не только в выборе темы, но и в языке» [Горький, 1913, с. 371]. По его мнению, следующий рассказ сборника - «Казнь» «еще более утверждает в том, что г. Кумов сильно зависит от Чехова» [Там же]. Горький полагает, что Кумов не столько учится у Чехова, сколько «списывает», нередко создавая своеобразные чеховские «копии». Они «не всегда слабые», но «все не нужны и вызывают чувство досады».

Впрочем, как отмечает Горький, у Кумова «несомненно есть свои темы, свои слова, свое - хорошее» [Там же]. Свою оценку таланта молодого писателя он подкрепляет подробным рассмотрением рассказа «Юбилей», приводя из него обширные цитаты. Завершая анализ рассказа, Горький приходит к выводу о самобытности таланта Кумова как писателя, который «умеет хорошо чувствовать святую правду той „несмелой, тысячелетней, рабской нищеты” материальной и духовной, которая серой тучей неподвижно стоит над жизнью русской деревни. Чувствуя эту правду, он умеет говорить о ней своими словами, умеет найти в ней что-то новое, поучительное и трогающее за сердце» [Горький, 1913, c. 372].

Кроме того, по мнению Горького, рассказы «Песня», «Ученый», «Несчастье», «Проповедь», охарактеризованные им как «настоящие темы азиатской нашей действительности», свидетельствуют о том, что Кумов «умеет писать просто и кратко о страшной русской жизни» [Там же].

В заключение Горький приветствовал начинающего писателя, в котором «русская демократия найдет писателя-друга, верного свидетеля правды, художника, умеющего писать картины трудной ее жизни», если «автор отнесется серьезно к своему дарованию» [Горький, 1913, с. 373].

Спустя три года, в августе 1916 г. Кумов посылает Горькому для публикации в журнале «Летопись» свой небольшой рассказ «Вишни» и письмо, сохранившееся в архиве Горького. Оно свидетельствует о том, что творчество Кумова по-прежнему интересует Горького: «Я очень дорожу тем добрым, которое передали мне от Вашего имени о некоторых моих рассказах наши общие знакомые» [Архив А.М. Горького: КГ-нп/а 14-18-1, л.1].

Ответные письма Горького Кумову пропали вместе со всем архивом писателя во время Гражданской войны. Однако из следующего письма Кумова мы узнаем причины, по которым «Летопись» отвергла рассказ «Вишни»: Горький посоветовал предложить редакции нечто «более значительное, чем „Вишни”», хотя, по слову Горького, «и спелые». Кумов с пониманием и благодарностью отнесся к рекомендации старшего товарища по перу: «Вы, безусловно, правы, когда не советуете мне дебютировать в большом ежемесячнике „Вишнями” . Писатель признается, что послал этот рассказ только потому, что очень хотел послать Горькому что-нибудь, «а более солидного под руками не оказалось» [Архив А.М. Горького: КГ-нп/а 14-18-4, л. 2].

Размышляя о своей литературной деятельности, Кумов признается: «Серьезно я к своей писательской работе до сих пор, кажется, не отно- 
сился, работал как-нибудь, спустя рукава. Ваш редакторский совет - то самое, что мне нужно было всегда. Очень большой строгости к себе мне как-то не прививали при моей работе - ни обстоятельства, ни люди» [Там же, л. 2].

Мнение Горького было очень значимо для донского писателя. Он вспоминает о той роли, которую сыграл Горький в его литературной судьбе: «Ведь Максим Горький - это моя юность зеленая, потом университет весь - все, все обрызгано Вами, как парусник на море свежими зелеными бризами! Когда вышла моя книжка, самый значительный отзыв я получил с Капри через одного человека» [Там же, л. 2 об.].

Вновь посылая Горькому небольшой рассказ в декабре 1916 года и обещая прислать в следующий раз повесть, Кумов пишет: «Очень мне хочется иметь с Вами дело как с редактором, и простите, если это назойливо очень». Он сердечно благодарит Горького за ответное письмо, которое ему «было дорого и приятно до чрезвычайности» [Архив А.М. Горького: КГ-нп/а 14-18-2].

Однако вместо повести в апреле 1917 г. уже после февральской революции он отправляет большой рассказ «Малаша с Перекопских гор», написанный на донском материале. В прилагаемом письме Кумов отмечает: «Посылаю я Вам „Малашу с Перекопских гор”, хотя думаю, что Вам и „Летописи” теперь, вероятно, не до „Малаши”. Все-таки посылаю, а если не подойдет, особенно по теперешнему боевому моменту, в претензии, конечно, не буду» [Архив А.М. Горького: КГ-нп/а 14-18-3, л. 3].

Писатель поясняет, почему он выбрал именно этот рассказ: «Хотелось мне, помимо бытовой зарисовки, дать тенденцию большой всесветлой любви, проникающей землю и людей. Именно теперь, когда разгораются страсти, эта тенденция, кажется, была бы к месту» [Там же, л. 3-л. 3 об.].

В этом же письме Кумов делится с Горьким своими мыслями о февральской революции, которую он принял с воодушевлением: «Настроение здесь, на местах, неровное. Есть тревога. Очень нужно бодрящее слово, как это ни странно. Все-таки очень, очень радостно, несмотря на всякие обывательские страхи» [Там же, л. 3 об.].

По мнению Кумова, задача писателя в переломный момент истории - оказать духовную поддержку своим читателям: «Заканчиваю повесть и пьесу - все о больших характерах, все с этой мыслью ободрить уже тревожащихся, усомнившихся в звезде происходящих российских событий» [Там же].

Донской писатель внимательно присматривается к настроению простого человека, обывателя и делится своими наблюдениями с Горьким: «А все-таки теперешней обывательской психологией Вы займитесь, - это серьезная штука. При неудачно сложившихся обстоятельствах каких-нибудь она может вырастить мгновенно древо реакции, как самый лучший навоз» [Там же].

Как известно, февральская революция 1917 г. вначале обрадовала Горького, хотя он и понимал всю сложность и неоднозначность происхо- 
дящих событий. По мнению Л.А. Спиридоновой, Горький, «считая необходимым создать условия для духовного возрождения народа и развития интеллектуальных сил страны, <..> мечтал о расширении и углублении революции, но не в переходе ее от буржуазной к социалистической, а в соединении с культурной революцией» [Спиридонова, 2016, с. 80].

Последнее письмо Кумова к Горькому, датированное 9 февраля 1918 г., явилось непосредственным откликом на события Гражданской войны на Дону. Исторические источники отмечают, что во второй половине января 1918 г. наступил решительный перелом в противоборстве советских и антисоветских сил на Дону. 20 января произошел ожесточенный бой возле ст. Глубокой между партизанами Чернецова и красногвардейцами. В решающий момент боя казаки-фронтовики, наблюдавшие за его ходом, ударили по отряду Чернецова, в результате чего партизаны были разгромлены. После этого боя началось стремительное продвижение советских сил, практически не встречавших сопротивления, вглубь Донской области по направлению к Новочеркасску. 29 января А.М. Каледин созвал экстренное совещание объединенного войскового правительства, где заявил о безнадежности положения и сложил с себя полномочия атамана и председателя войскового правительства. После этого заседания генерал покончил с собой. Однако политическое и военное противостояние в Донской области продолжалось [Крестьянство и казачество России в условиях революции 1917 г. и Гражданской войны..., 2017, с. 634-635].

Столичные газеты подробно сообщали о событиях на Дону. Но не только поэтому Кумов не стал описывать то, что происходило на его родине: «Царапаю Вам это послание с Дона, который стал за эти последние месяцы, увы, не тихим и не синим. <..> Что у нас, в степях донских, делалось эти месяцы, Вы, вероятно, знаете уже. И я не буду об этом писать, потому что это очень тяжело мне» [Архив А.М. Горького: КГ-П 41-21-1, л.1].

Мысли и чувства, выраженные Кумовым в этом письме, оказываются близки идеям Горького, которые он высказал ранее в цикле статей, опубликованных в газете «Новая жизнь» в 1917-1918 гг. и собранных позднее под заглавием «Несвоевременные мысли». На страницах «Несвоевременных мыслей» М. Горький выступает с позиций гуманизма. Писатель выражает протест против разрушения исконных основ русской жизни, анархии, нигилизма, неоправданного насилия, против уничтожения интеллигенции [Спиридонова, 2016, с. 81].

Кумов видит причину происходящих на Дону трагических событий в недобросовестной политической борьбе: «Зараза плохой русской внутренней политики и подлого политиканства проникла и в наши девственные места и произвела опустошения больше, чем чума и холера! Всюду кровь, злоба, подозрительность, звериные крики и звериный вой. Будь она проклята - эта политика!» [Архив А.М. Горького: КГ-П 41$21-1$, л.1] 
Сходные мысли о политике высказывал и М. Горький: «Политика почва, на которой быстро и обильно разрастается чертополох ядовитой вражды, злых подозрений, бесстыдной лжи, клеветы, болезненных честолюбий, неуважения к личности...» [Горький, 1990, с. 113]

По мнению Кумова, «бороться с теперешней российской геенной огненной можно не политическим путем, а общекультурным» [Архив А.М. Горького: КГ-П 41-21-1, л. 1 об.]. И Горький противопоставляет культурную работу политической борьбе: «Я знаю, что политическая борьба - необходимое дело, но принимаю это дело, как неизбежное зло. $<$...> Задача культуры - развитие и укрепление в человеке социальной совести, социальной морали, выработка и организация всех способностей, всех талантов личности, - выполнима ли эта задача во дни всеобщего озверения?» [Горький, 1990, с. 127-128].

Противопоставляя культуру «подлой» политике, Кумов размышляет о той роли, которую «во дни всеобщего озверения» должна взять на себя интеллигенция: «Ошибка сознательных элементов в России сейчас в том, что они пытаются кого-то убедить, когда этот кто-то сейчас в полном горячечном беспамятстве. Надо не убеждать, а лечить. Россия сейчас уже не митинг, а собрание заболевших психически людей. Надо, по возможности, постараться успокоить российского человека. Надо отвести его болезненно загипнотизированный взгляд от точки, на которой он заболел, на другие предметы, которых так много в мире, и о которых современный русский человек совершенно забыл. Особенно надо напомнить ему о других, высших интересах. Надо же, чтоб над оземленившейся до цинизма и до трагизма Россией появился, наконец, животворящий дух!» [Архив А.М. Горького: КГ-П 41-21-1, л. 1].

Донской писатель приходит к выводу, что «единственный путь к спасению нашей родины - путь напряженнейшей и одухотворенной культурной работы». Писатель не сомневается в правильности этого пути: «Пускай кое-кто продолжает и дальше разжигать в нашем темном российском человеке зверя, - мы, в противовес ему, будем стараться укрепить в новоявленном гражданине человека. И я глубоко верю, что победа будет на нашей стороне, а не на стороне наших противников» [Там же, л. 1-л. 2].

Эту же мысль писатель подчеркивает в письме к А.А. Измайлову, написанном несколькими днями ранее, 30 января 1918 г.: «Насколько я понимаю, главная задача интеллигентных сил сейчас в России - вести общекультурную работу в противовес работе политической, которая разожгла в человеке зверя. Теперь мы должны соединяться в кружки, в артели, в издательства и окачивать холодной водой неразволочную российскую драку, начатую из-за „земли и воли”. Надо звать людей к миру, - в первую голову» [Кумов: Письма Измайлову, 1918, л. 75 об.].

Нельзя не заметить, что в «Несвоевременных мыслях» М. Горький неоднократно утверждает, что единственный путь спасения России культурное строительство: «Опять культура? Да, снова культура. Я не знаю ничего иного, что может спасти нашу страну от гибели. И я уверен, 
что если б та часть интеллигенции, которая, убоясь ответственности, избегая опасностей, попряталась и бездельничает, услаждаясь критикой происходящего, если б эта интеллигенция с первых же дней свободы попыталась ввести в хаос возбужденных инстинктов иные начала, попробовала возбудить чувства иного порядка, - мы не пережили бы множества тех гадостей, которые переживаем» [Горький, 1990, с. 92].

Эта новая идейная программа писателя, которого после Октябрьской революции стали именовать ее «Буревестником», воплощалась Горьким в грандиозных просветительских проектах, направленных на популяризацию культуры в широких слоях общества. Так, писатель планировал издание лучших произведений мировой литературы, энциклопедии для рабочих, истории русского народа. Октябрьский переворот и последовавшие за ним события заставил его испугаться за судьбы культуры [Спиридонова, 2016, с. 79-80].

По мысли Горького, «хорошая, честная книга, - лучшее орудие культуры» [Горький, 1990, с. 125-126]. Словно подтверждая эту мысль, Кумов в своем письме описывает «два маленьких эпизодика», в которых, по наблюдению писателя, очевидно примиряющее влияние литературы: «летом, на одном концерте с участием политических ораторов, по моей просьбе выступил один педагог с рассказом Л. Толстого „Чем люди живы”, и я видел, и видели все, что победил Толстой с своим словом о любви, а не те, кто звал к пролитию крови. Другой эпизод: поставили Ваше „На дне” в народной аудитории накануне митинга, который обещал быть особенно кровожадным. И даю Вам честное слово, что на другой день на этом митинге я видел у самых неистовых ораторов какое-то смущение, и не было произнесено ни одного этого дьявольского слова с призывом лить кровь, как воду» [Архив А.М. Горького: КГ-П 41-21-1, л. 2].

Сохранились только пять писем Кумова Горькому. Вероятно, дальнейшая переписка в условиях Гражданской войны становится невозможной. После того, как родная станица Усть-Медведицкая была в очередной раз занята красными, Кумов уходит в Новочеркасск, где умирает от тифа 20 февраля 1919 г. По решению Войскового круга он был похоронен с воинскими почестями как национальный писатель Дона. На смерть Кумова откликнулся в газете «Донская волна» Федор Крюков: «Его имя известно было родному краю далеко не в той степени, как оно этого заслуживает. До обиды мало известно. Войсковой Круг - соль Донской земли - почтил отошедшего писателя национальным погребением. Но ведь здесь, в сосредоточии надежд и тревог казачества, в центре, созидающем оборону веками сложившегося казачьего уклада, выковывающем спасение России, никто не подозревал, что вблизи Круга работал скромно, бескорыстно, самоотверженно замечательный писатель-казак, отдавший тем же тревогам, заботам и упованиям весь жар своего редкостного сердца» [Кумов, 2008, с. 486].

В советское время имя Кумова и его творчество были обречены на забвение. Этим объясняется ответ К. Федина на вопрос Горького 
о судьбе писателя. Мы полагаем, что Горький неслучайно вспомнил донского писателя и его драму о камских лесопромышленниках «Конец рода Коростомысловых» в 1924 году. В конце 1923 - начале 1924 года Горький возвращается к своему давнему замыслу и начинает работу над романом о вырождении и упадке буржуазной семьи, получившем название «Дело Артамоновых» (цит по:[Овчаренко, 1982, с. 152]).

Образы и мотивы драмы Кумова, посвященной теме угасания древнего купеческого рода, оказались типологически созвучны творческому замыслу Горького. И в романе Горького, и в драме Кумова сквозным является мотив греховной любви, ведущей к распаду семейных отношений. Такова страстная любовь Ильи Артамонова и Ульяны Баймаковой, ставших родственниками после свадьбы детей в романе Горького, и любовь Кузьмы Коростомыслова к Татьяне Хлудовой, оказавшейся дочерью его брата Степана, а также любовь сына Степана Николая к Татьяне, его сестре в пьесе донского писателя.

Нельзя не отметить, что существует определенное сходство между героем Горького - сыном Ильи Артамонова, горбуном Никитой и персонажем драмы Кумова - Степаном Коростомысловым, в судьбах которых прослеживаются мотивы ухода-возвращения и презрения к мирским благам, восходящие к «Житию Алексия, человека Божия».

Однако несмотря на созвучие целого ряда образов и мотивов романа и драмы, их авторы решали принципиально разные и по масштабу, и по проблематике творческие задачи. Если Кумов стремился показать победу духа над капиталом, духовного начала над звериным и стяжательским [Заяц, 1994, с. 229], выдвигая на первый план религиознонравственные проблемы, то для Горького важно было проследить «закономерность угасания и подъема целого класса, необратимость этого процесса, в связи с творческой исчерпанностью класса, смены его новой исторической силой» [Овчаренко, 1982, с. 154].

Нам представляется, что письма Кумова к Горькому, впервые вводимые в научный оборот, позволяют не только заполнить «белые пятна» в творческой биографии донского писателя, но и воссоздать историю его литературных отношений с великим писателем-современником.

\section{Литература}

Архив А.М. Горького: КГ - нп/а $14-18-1$.

Архив А.М. Горького: КГ - нп/а $14-18-2$.

Архив А.М. Горького: КГ - нп/а $14-18-3$

Архив А.М. Горького: КГ - нп/а $14-18-4$.

Архив А.М. Горького: КГ - П $41-21-1$.

[Горький М.] А. 3-в // Современник. 1913. Кн.7. С. 371-373.

Горький $M$. Несвоевременные мысли: Заметки о революции и культуре. М.: Советский писатель, 1990.400 с.

Горький и советские писатели: Неизданная переписка / АН СССР. Ин-т мировой лит. им. А. М. Горького; ред. тома И. С. Зильберштейн и Е. Б. Тагер. М.: Изд-во АН СССР, 1963. 736 с.: ил. (Лит. наследство. Т. 70). 
Заяи А.А. Кумов Р.П. // Русские писатели 1800-1917. Биографический словарь. Т. 3. М.: Большая Российская энциклопедия, 1994. С. 227-229.

Крестьянство и казачество России в условиях революции 1917 г. и Гражданской войны: национально-региональный аспект: монография / В. В. Кондрашин, В. А. Юрчёнков, Д. И. Люкшин и др.; редакционная коллегия: В. В. Кондрашин [и др.]. М.; Саранск: НИИ гуманитарных наук при Правительстве Республики Мордовия, 2017. 1046 с.

Кумов Р. П. Избранное / сост. В.И. Супрун. Волгоград: Изд-во ВГИПК РО, 2008. $564 \mathrm{c}$. 1913.

Кумов Р.П. В Татьянину ночь. СПб: книгоиздательство «Жизнь для всех»,

Кумов Р.П. Письма А.А. Измайлову // Институт русской литературы (Пушкинский дом) (ИРЛИ). ф. 115. д. 170.

Медведева M.A. Гольденберг А.X. Тема бессмертия души в творчестве Р.П. Кумова // Электронный научно-образовательный журнал ВГСПУ «Грани познания». № 8(42). Ноябрь 2015. C. 149-152. URL: www.grani.vspu.ru / http:// grani.vspu.ru (дата обращения 20.09.2019).

Овчаренко А.И. М. Горький и литературные искания ХХ столетия. М.: Худож. лит., $1982.512 \mathrm{c.}$

Спиридонова Л.А. Настоящий Горький: мифы и реальность. 2-е издание, измен. Нижний Новгород: ООО «БегемотНН», 2016. 384 с.

\section{References}

Arkhiv A.M. Gor'kogo: KG - np/a $14-18$ - 1. (In Russian)

Arkhiv A.M. Gor'kogo: KG - np/a $14-18-2$. (In Russian)

Arkhiv A.M. Gor'kogo: KG - np/a $14-18$ - 3 (In Russian)

Arkhiv A.M. Gor'kogo: KG - np/a $14-18$ - 4. (In Russian)

Arkhiv A.M. Gor'kogo: KG - P 41 - 21 - 1. (In Russian)

[Gor'kii M.] A. Z-v Sovremennik, 1913, Kn.7, pp. 371-373. (In Russian)

Gor'kii M. Nesvoyevremennye mysli: Zametki o revolyutsii i kul'ture, Moscow, Sovetskiy pisatel', 1990, 400 p. (In Russian)

Gor'kii i sovetskiye pisateli: Neizdannaya perepiska, AN SSSR. In-t mirovoy lit. im. A. M. Gor'kogo; red. toma I. S. Zil'bershteyn i Ye. B. Tager. Moscow: Izd-vo AN SSSR, 1963, 736 p.: il. (Lit. nasledstvo. T. 70). (In Russian)

Krest'yanstvo i kazachestvo Rossii v usloviyakh revolyutsii 1917 g. i Grazhdanskoy voyny: natsional'no-regional'nyi aspekt: monografiya $V . V$. Kondrashin, V. A. Yurchyonkov, D. I. Lyukshin i dr.; redaktsionnaya kollegiya: V. V. Kondrashin i dr. M.; Saransk: NII gumanitarnykh nauk pri Pravitel'stve Respubliki Mordoviya, 2017, 1046 p. (In Russian)

Kumov R. P. Izbrannoye, sost. V.I. Suprun, Volgograd: Izd-vo VGIPK RO, 2008, 564 p. (In Russian)

Kumov R.P. V Tat'yaninu noch', St. Petersburg: knigoizdatel'stvo «Zhizn' dlya vsekh», 1913. (In Russian)

Kumov R.P. Pis'ma A.A. Izmaylovu Institut russkoy literatury (Pushkinskiy dom) (IRLI), f. 115, d. 170. (In Russian)

Medvedeva M.A. Goldenberg A.Kh. Tema bessmertiya dushi v tvorchestve R.P. Kumova. Elektronnyi nauchno-obrazovatel'nyi zhurnal VGSPU «Grani poznaniya». № 8(42). Noyabr' 2015. pp. 149-152. Available at: http://grani.vspu.ru/publics/get?h ash=e5e63da79fcd2bebbd7cb8bf1c1d0274 (accessed 20.09.2019). (In Russian) 
Ovcharenko A.I. M. Gor'kii i literaturnyye iskaniya XX stoletiya, Moscow: Khudozh. lit., 1982, 512 p. (In Russian)

Spiridonova L.A. Nastoyashchii Gor'kiy: mify i real'nost', 2-ye izdaniye, izmen. Nizhniy Novgorod: OOO «BegemotNN», 2016, 384 p. (In Russian)

Zayats A.A. Kumov R.P. Russkie pisateli 1800-1917. Biograficheskii slovar', T. 3. Moscow: Bol'shaya Rossiyskaya entsiklopediya, 1994, pp. 227-229. (In Russian)

Maria A. Medvedeva (Volgograd, Russian Federation)

R.P. Kumov and M. Gorky: History of Literary Relations The article deals with the history of literary relations of R.P. Kumov and M. Gorky. The correspondence of writers is analyzed, which reveals the role of M. Gorky in the creative biography of R.P. Kumov. Typological connections are established between M. Gorky's novel «The Artamonov's Affair» and R.P. Kumov's drama «End of the Korostomyslov family».

Key words: R.P. Kumov, M. Gorky, literary relations, creative biography.

Maria A. Medvedeva - assistant, department of Russian as a Foreign Language, Institute of Russian Language and Literature, Volgograd State Social and Pedagogical University. Phone:: +7 (927) 065-90-66, e-mail: mary-medved.medvedeva@yandex.ru 